\title{
トレンチ掘削による利根川河岸の発達過程の研究
}

\section{A trench test on formative process of the riverbank of the Tone River}

\author{
藤井 政人*·宇多 高明**・深谷 涉*** \\ by Masato FUIII, Takaki UDA and Watanu FUKATANI
}

This study aims to develop a renewal or conservation method of the riverbank with or without bank protection works. As the first step, a trench test was carried out at the natural riverbank of the Tone River, where the riverbank was formed by the installation of several spur dykes in the $1960 \mathrm{~s}$, in order to investigate formative process of the natural riverbank. It is concluded through this field investigation that formative process and the developing velocity of riverbank strongly depend on changes in the water and bank lebel,and the enhancement of depositional effect of fine sediments due to the growth of vegitation on the riverbank.

Key words: Natural riverbank, Sedimentation, Trench test, Spur dyke

\section{1.はじめに}

最近までの河岸防御の考え方は、堤防の前面にある高水敷の河岸線を洪水防御の最前線と位置づけ、コン クリート張ブロック護岸などにより河岸線を覆うことにより、河岸の耐侵食力を向上させるというすのであ った。しかし河岸侵食を防ぐという意味では、土砂が河岸に堆積し易い環境を整え、川本来の作用を利用し て新しい自然河岸を積極的に造って行くことも、広義の河岸防御手法であるといえる。また河岸では、低水 路河床の変化ほど速くはないが、高さや平面形状が治水上有為な速度を持って変化することが、最近の調查 から明らかにされている。

一方、多くの自然河岸では良好な自然環境が保たれており、そのような環境を保全することが是非必要と されている。したがってこの意味からす自然河岸の形成について考えることは有意義である。自然河岸の形 成を促進させる上からは、何らかの形で问岸近傍の流速を低減させることが必要とされるが、そのような目 的を達し得る構造物として古くから用いられているすのに水制工がある。そしてその流速低減効果について

* 正会員 建設省土木研究所河川研究室 研究員

(テ305 茨城県つくば市大字旭 1 番地)

** 正会員 工博 建設省土木研究所河川研究室長

*** 正会員 建設省土木研究所河川研究室 
は、例えば秋草ら”による詳細な研究が行われている。し かし、水制周辺での土砂堆積の促進という意味からは、十 分な検討がなされていないようである。同様に、自然河岸 の形成過程む十分に明らかにされておらず、水理学的ある いは生態学的に最適な自然河岸を形成させる技術は十分な 発展段階にあるとはいえないのが現状である。

本研究は、自然河岸の保全工法や積極的な形成手法の開 発を最終目標とする。自然河岸の形成過程では、洪水時に おける河岸付近での流水の挙動と土砂堆積、植生の繁茂状 況など様々な要因が複雑に絡み合い、実験的に現象を再現 することは非常に困難である。そこで、今回その第一歩と して河岸の発達過程を把握することを目的として、ある時 期から急速に成長した自然河岸に注目し、その横断形状の 変化を調べるとともに、トレンチ掘削による堆積物と堆積 構造についての詳細な現地調查を行った。さらに、発達段 階において河岸に作用した外力条件（水位履歴など）を調 べ、上述の調查結果とともに河岸の発達機構について検討 した。

\section{2. 研究方法}

\section{1年撮影}

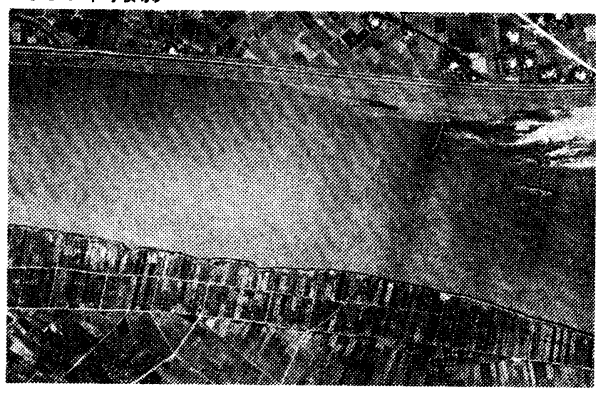

1974年撮影

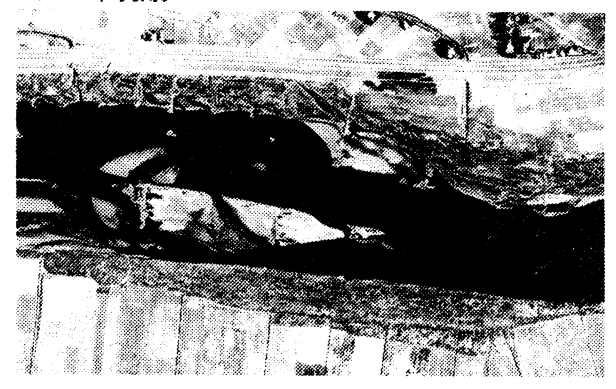

写真 - 1 利根川の調査対象河岸の空中写真

調查地点は、(1)土砂が自然に堆積して形成された河岸、 (2)堆積が急速に生じた河岸、(3)横断形状の变遷が追える河 岸、および(4)外力条件（水位など）の履歴が追える河岸、 をもとに選定した。その結果、利根川の $123.5 \mathrm{~km}$ 地点左岸が 調查対象河岸として選定された。写真-1は調查対象河岸付 近を撮影した空中写真である。これらの写真を比較すると、 1961年当時には杭出し水制が設置されているのみで、自然 河岸の形成は認められない。しかし、1974年では水制間に 土砂が堆積し自然に河岸が形成されたことがわかる。この ことから、当地は本研究の遂行上、非常に良好な研究サイ トである。

調查は、トレンチ掘削と断面内の土質構造調查に分けら れる。トレンチ掘削の範囲は、予め調查予定地の詳細な平

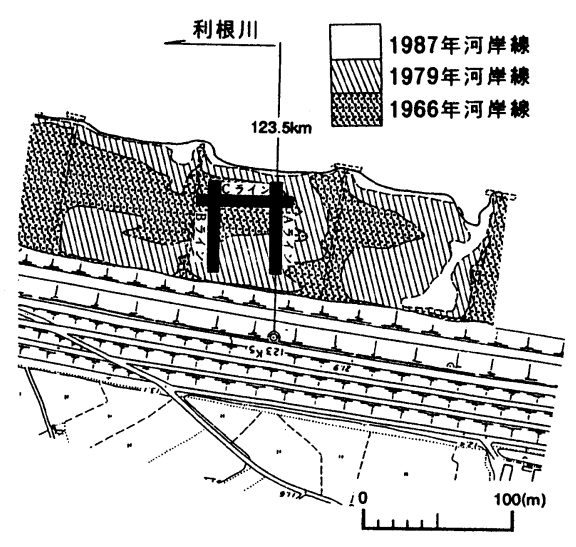

図-1

\section{利根川河岸の河岸線の変景}

板測量を行い、樹木の位置などを把握した上で、図-1に示すように横断 方向のトレンチを2本（A，Bライン）、河岸部において縦断方向のトレ ンチ（Cライン）を1本掘削した。ここにAラインは水制の下流側約 $10 \mathrm{~m}$ に、Bラインは下流側の水制近傍に位置する。また断面内の土質構造調 査は、各トレンチの端から $5 \mathrm{~m}$ ピッチに定めた鉛直測線で行い、層の区分 ・各層の土質・各層上面の深さを測定した。また土質区分には、表-1に 示す土質分類を用いた。

\begin{tabular}{|c|c|c|c|}
\hline \multicolumn{2}{|c|}{ 表 -1} & \multicolumn{2}{|c|}{ 土質分類 } \\
\hline 材 料 & 粒 & 径 & (mm) \\
\hline 蹅 & & $\sim$ & 40.0 \\
\hline 砂 利 & 40.0 & $\sim$ & 2.0 \\
\hline 粗 砂 & 2.0 & $\sim$ & 0.5 \\
\hline 中 砂 & 0.5 & $\sim$ & 0.3 \\
\hline  & 0.3 & $\sim$ & 0.074 \\
\hline シルト & 0.07 & $4 \sim$ & \\
\hline
\end{tabular}




\section{3. 河岸の土質構造}

代表としてBラインの土質構造を図-2に示す。 図中の上段は B ラインの概略の層構造である。下 層の粗砂層と示した部分は、自然河岸が形成され る前の河床 (初期河床) に相当し、その平均粒径は 約 $0.5 \mathrm{~mm}$ である。一方、上層の細砂層の平均粒径は 細かく、層によっては $0.4 \mathrm{~mm}$ 程度の平均粒径を示す 首むあるが、ほとんどは $0.3 \mathrm{~mm}$ 以下の微細砂やシル トであった。このことから、河岸は低水路の河床 材料よりあ細かい粒径のあので構成されており、 そのほとんどは浮遊砂として河岸上に運ばれ、堆 積したものであると考えられる。また、細砂層と シルト層の境界は非常に明瞭に判別され、この高 さはシルトと細砂の堆積の限界高さに相当すると 考えられる。さらに、細砂層をみれば横断距離 30 〜 65mの間で特に砂の堆積が著しく、ほぼ一定 (約 $50 \mathrm{~cm})$ の層厚を有している。また、細砂は河 岸と低水路の境界から横断方向に高々 $40 \mathrm{~m}$ 程度し か到達し得ないといえる。

細砂層の詳細を下段の拡大図に示す。この層は 細かく見ると細砂層と細砂混じりシル卜層の互層 であり、若干のシルト層が含まれる。このことか ら河岸が形成されるときには、土砂は明瞭な層構 造を形成しつつ堆積することが分かる゙)。これら の層を構成している土質は各々異なっていること から、各々の層は過去の洪水履歴と対応している と考えられ、その首が形成されたであろう洪水を 特定することができれば、洪水時の水理量から河 岸を形成する条件を定量的に評価することが可能 であろう。また、上層のシルト層にも同様な層構 造が見られた場所むあったが、植生の根が層の中 にかなり複雑に侵入しており、これにより乱され た状態にあったので、確認はできなかった。

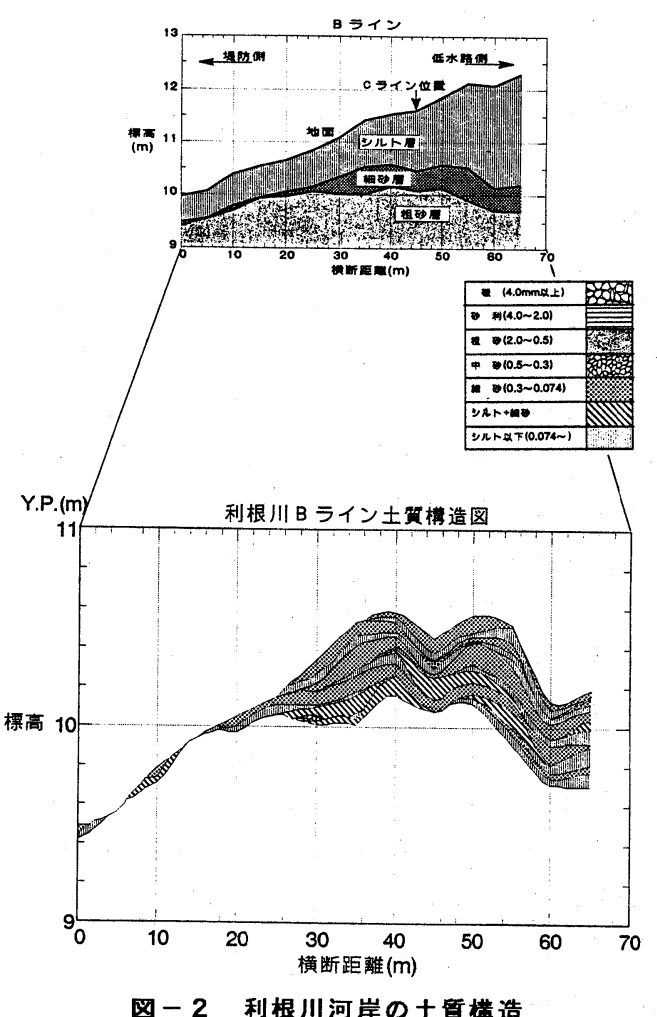

図-2 利根川河岸の土質構造

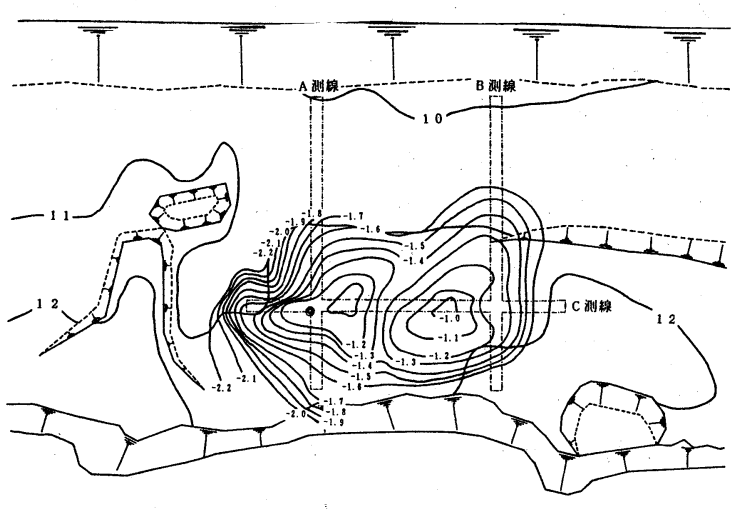

図ー3 砂庴上面の等高楾

図-3は、図-2の上段に示した細砂層の上面の等高線を示している。ここに等高線は A、C両ラインの交点 （○印）の地盤高を基準として、それに対する砂層上面の高さを $\mathrm{m}$ 単位で示した。この図を見ると、Cライ ン上で $2 つ$ 細砂のマゥンドが認められる。上流側の A ラインとCラインの交点付近のマウンドは、堤脚側 に向かって急峻な地形である。これは上流側の水制により水制間に引き込まれた流れが、このマゥンド付近 で大量に土砂を堆積させたためと考えられる。一方、下流側のマゥンドは河岸側は比較的急であるが、堤脚 側は緩やかな傾斜をしており、下流側水制の基部に向かってのびている。このことから、下流側のマゥンド は数回の洪水を経て、土砂が緩やかに沈降して堆積して形成したと考えられる。 


\section{4. 河岸の形状変化}

調査対象河岸の横断形状の経年変化を図-4に示す。 横断形状の変化の特徵として、低水路と河岸の境界付 近での河岸高の変化が著しく、逆に低水路の河床が低 下して、河岸と低水路の境界で段差が発生しているこ とが挙げられる。このように河岸前面で段差が発生す ると、河岸と低水路の境界付近で掃流力が急激に変化 し、河岸上の掃流力は低水路内に比較して非常に小さ くなる。このとき低水路から河岸上に運ばれた浮遊砂 は、掃流力の急激な変化により河岸と低水路の境界付 近で大量に堆積するので、境界付近の河岸高の変化が 大きくなると考えられる”。

このような段差が発達し過ぎると、河岸上に運ばれ る浮遊砂の大半はシルトとなる。シルトは洪水時にウ オッシュロードとして運ばれ、これが堆積するには河 岸上の流速が非常に遅くなるか、あしくは洪水の減水 期や小洪水時のように水面勾配が非常に緩やかな時期 でなければならない。したがって、河岸上の各層の堆 積厚は非常に小さくなる。一方、段差の増大に伴って 洪水時には河岸前面での水深が大きくなるので、河岸 前面に作用する掃流力が增大し、河岸侵食の発生が考 えられる。しかしながらこの例のように、河岸に水制 が設置されていると、河岸前面に作用する掃流力が小 さくなるので河岸侵食が防止されたと考えられる゙。

利根川の平水位は河床低下にとすなって低下してき ている(図-4参照)。1961年の平水位は当時の河岸高 より高く、冠水深は約 $1 \mathrm{~m}$ である。一 方、1975年時点での平水位は河岸高 より低い位置にあり、河岸の冠水頻 度は年に数十回程度になる。このよ うに、特に平水位が河岸高より低く なると、水面から露出した部分に植 生が侵入して洪水時の河岸上の流速 は遅くなり、河岸上への土砂堆積は より促進される。したがって河岸の 成長速度は速くなると考えられる。

自然河岸の形成を促進させようと する場合、自然河岸がどのような速 度で成長するのかを知ることが非常 に重要である。自然河岸が数年のオ ーダーで成長するのであれば、あえ

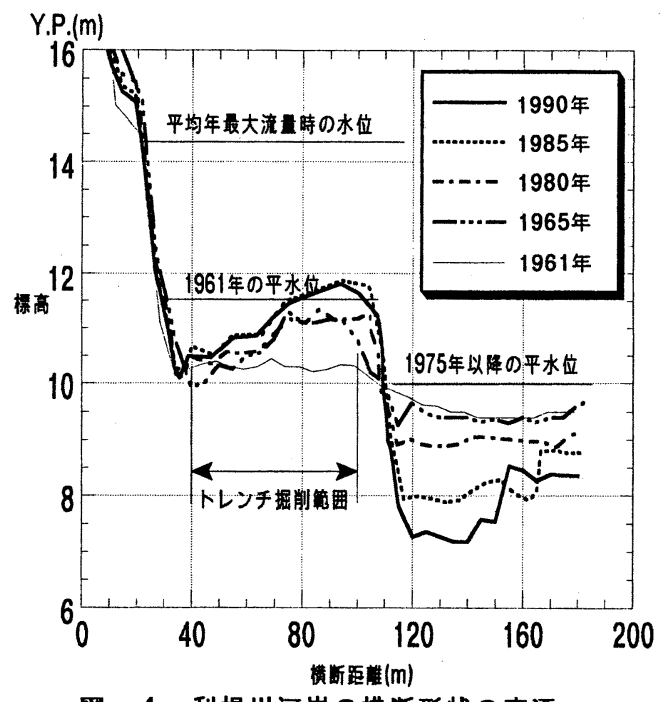

図-4 利根川河岸の横断形状の変哑

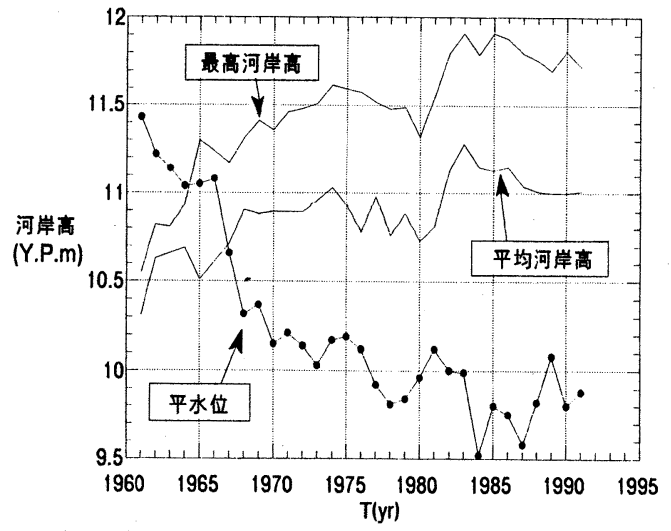

図-5 河岸高の変霞（最高点の高さ）

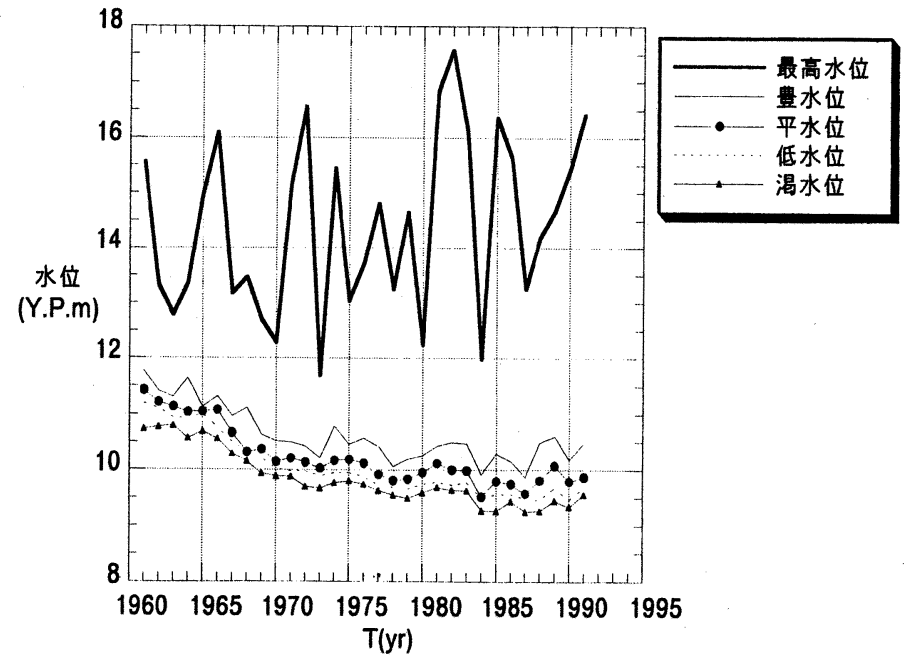

図一 6 利根川の位況 
て河岸形成を促進させずとす、自然河岸を形成させた い場所を確保し、条件を整えて現在の状態を維持して やれば自然河岸は自動的に形成される。しかし、自然 河岸が50あるいは100年というオーダーで形成されるな らば、自然河岸が形成される間に河道そのものが変化 したり、河川空間で自然環境を保全しょうというニー ズそのあのが失われか称ない。したがって、自然河岸 の形成を促進させようとする場合、長くとむ5 10年で 自然河岸が形成されるような手法が必要となってくる。 自然河岸の形成過程で非常に重要なことは、洪水履 歴である。そこで、自然河岸の発達速度と河岸の冠水 頻度との関係を調べてみた。図-5は利根川の河岸高と 平水位の経年変化を、図-6は利根川の位況の経年変化 を示したあのである。また図-7は河岸の5年間の平均発 達速度を経年的に示したすのである。図-5を見ると、 既に1964年時点で河岸の最す高い位置は平水位とほぼ 同じレベルにまで成長している。それ以後、特に1969 年までの 5 年間で約 $50 \mathrm{~cm}$ あ高くなっており、その前後の 変化と比較してもこの時期の河岸の発達が非常に速く、 植生が繁茂したことが大きな影響を及ぼしていること がわかる。また1964年以前の河岸す1961年からの3年間 で約 $30 \mathrm{~cm}$ す発達しているが、これは水制が設置された ことにより、河岸上の流速が遅くなり河岸への土砂堆 積が促進された結果であると考えられる。図一より平 均河岸高の発達速度を見ると、1967年前後で最も速く $13 \mathrm{~cm} / \mathrm{yr}$ 、最高河岸高は1963年前後で最も速く $20 \mathrm{~cm} / \mathrm{yr}$ である。その後、1980年までは発達速度が徐々に遅く なっていき、1975年から1979年までの5年間はほとんど 成長が見られなくなっている。ところが、1981年から

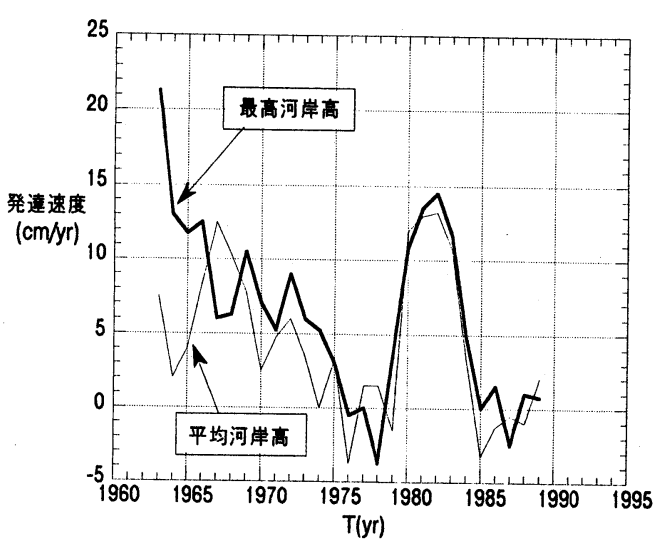

図-7 自然河岸の発達速度

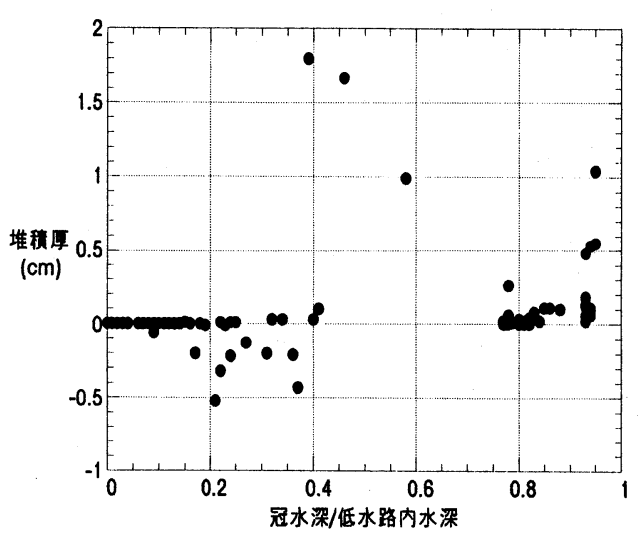

図-8 冠水深/低水路内水深と堆皘厚の関係 1985年までは新たな発達段階を迎えており、特に1982年までの 2 年間で約 $60 \mathrm{~cm}$ の河岸の発達を記録している。 図-6の既往洪水との関係をみれば、1975年から1980年の5年間は、それほど大きな洪水は発生していない。つ まり、河岸上の冠水樑は大きくはならず、また当時の河岸と低水路境界の段差が約 $2 \mathrm{~m}$ にまで発達していたの で、中小洪水時では河岸上に大量の土砂を堆積させるには至らなかったと考えられる。ところが、1981年以 後3年間にわたり、非常に大きな洪水が数回発生している。これらの洪水は河岸の冠水深が非常に大きかった ため、それ以前の洪水では河岸上に運ばれ得なかった土砂が河岸上に多量に運ばれ堆積したと考えられる。

以上のことから、自然河岸の発達は河岸上の冠水深と低水路境界の段差に強く依存すると考元られる。図 一8は、過去に発生した洪水について、低水路内の水深に対する冠水深の比（ $\mathrm{h}_{\mathrm{r}}$ ) を横軸に、河岸の堆積厚を 縦軸に取って両者の関係を示したすのである。ここに、 $\mathrm{h}_{\mathrm{r}}$ が大きい時には冠水深が大きく、段差が小さいこ とを意味する。この図より、洪水時の河岸上の冠水深が低水路内の水深の約半分となるょうな水樑の時に河 岸上への土砂堆積は最む大きいことがわかる。 


\section{5. 河岸の発達条件}

自然河岸の形成を促進させる主な要因は以下の通りである。

(1)河岸と低水路の境界での段差の発生 : 低水路河床高と河岸高の差が大きくなる（段差の発生）と、低水路 と河岸とでは掃流力の差が大きくなる。したがって低水路から輸送された浮遊砂は河岸上で掃流力の低下に とすない河岸上に堆積することになる。段差が発生する要因としては、砂利採取などにより低水路が河床低 下するか、河岸の耐侵食性が大きく低水路の河床低下に追随できなかったか、あるいは河岸の構成材料は低 水路の河床材料と同様のあのであるが、水制などが設置されているため材料の流出が妨げられたことなどが 考えられる。利根川の事例では、河岸上の水深が低水路内水深の半分程度の場合に河岸上への堆積厚が大き くなる。

(2)平水位の低下 : 要因(1)により河岸が低水路に比較して相対的に高くなり、平水位以上にまで高くなると、 河岸に堆積した土砂が非洪水時に流出しなくなる。

(3)植生の侵入 : 要因(1)、(2)により河岸が高くなると植生が河岸に侵入する。これにより洪水時に河岸に輸送 される浮遊砂がより一層堆積し易くなる。

(4)水制の設置 : 河岸に水制が設置されたことにより、低水路と水制域の間に掃流力の差が生じるので水制域 には土砂が堆積し易くなる。また、河岸の形成が進むと低水路の川幅は河岸形成以前に比較して狭くなり、 洪水時の水深が深くなるので河岸に作用する摩擦速度はより大きくなる。したがって耐侵食性が大きくなけ れば形成された河岸は維持されないが、水制が設置されたことにより、河岸に作用する摩擦速度が小さくな って河岸が維持されたと考えられる。

\section{6. まとめ}

本研究により、自然河岸は明瞭な層構造を持っていることが示された。また、自然河岸が形成される場合、 河岸と低水路境界付近での発達が非常に速く、その結果形成される段差がさらに河岸の形成を促進させるこ とがわかった。さらに、河岸の発達速度は河岸形成過程の初期では遅いが、ある適当な段差と洪水頻度、冠 水深が与えられれば、急速に発達しうることが示された。これらのことから、自然河岸の形成を促進させる 場合、発達速度があっとも速くなるような段差をあらかじめ造っておく、あるいは段差と同様の効果を発揮 する構造物を設置することなどが有効な手段として考えられる。本研究では、利根川を対象として水制間に 形成された自然河岸の形成過程、発達速度について検討した。しかし、水制がなくとも土砂が堆積して自然 河岸が形成された事例むあるので、それらについてす調查する必要がある。それらの調査を通じて、様々な 条件下で形成される自然河岸の形成機構を調查する必要があろう。

\section{参考文献}

1)秋草 勲・吉川秀夫・坂上義次郎・芦田和男・土屋昭彦 (1960) : 水制に関する研究, 土木研究所報告, 107号の6, pp. 1-93.

2) 藤井政人・山本晃一・深谷 涉(1993)：河岸形成過程に関する研究〜利根川・川内川での土砂堆積の実態 調查〜，河道の水理と河川環境シンポジゥム, pp. 155-162.

3)山本晃一・藤田光一・佐々木克也・有澤俊治(1993): 低水路川幅変化における土砂と植生の役割, 河道の 水理と河川環境シンポジゥム, pp. 233-238.

4)山本晃一(1992)：現代水制論，土木研究所資料，第3049号，pp. 288-305. 